CENDEKIA, Vol. 12, No. 2, Oktober 2018

p-ISSN: 1978-2098; e-ISSN: 2407-8557

Http://cendekia.pusatbahasa.or.id; Email: cendekiaoslo@gmail.com

Center of Language and Cultural Studies, Surakarta, Indonesia

Budiharso, Teguh. 2018. Pembelajaran Menulis Esai dalam Disertasi: Kajian Metakognitif.

Cendekia (2018), 12(2): 141-152. DOI:10.30957/cendekia.v12i2.535.

\title{
PEMBELAJARAN MENULIS ESAI DALAM DISERTASI: KAJIAN METAKOGNITIF
}

\author{
Teguh Budiharso \\ Universitas Mulawarman, Samarinda \\ Email: proteguh@gmail.com
}

\begin{abstract}
Four dissertations on writing subject are analyzed in this study implementing metacognitive analyses. The analysis focused on overall aspects how research procedures are employed and how the findings of those dissertations are modified for the purpose of a new research on similar concerns. The study reveals that prospective research topics in writing are available. Both approaches and topics of writing are offered from which research designs vary. Quantitative approaches using experimental study may be focused on the testing of teaching methods in writing, writing strategies, writing process, and techniques of writing. Rhetoric and linguistics aspects of writing are topics from which researchers can develop with various objectives. Specifically, assessment on writing is a prospective field that is recently required in relation to the performance assessment. In addition, developing teaching materials on writing of which Research and Development (R\&D) design is applicable is also demanding.
\end{abstract}

Keywords: writing aspect, metacognitive, assessment, experiment.

\section{DOI:10.30957/cendekia.v12i2.535.}

\section{PENDAHULUAN}

Penelitian ini mengkaji disertasi bidang menulis esai untuk input perencanaan menulis disertasi baru. Kajian dilakukan terhadap empat disertasi sebagai bahan eksplorasi. Kajian dimaksudkan untuk menemukan model disertasi yang meliputi aspek-aspek mendasar pengembangan penelitian untuk disertasi. Secara spesifik, aspek tersebut meliputi: variabel penelitian, permasalahan, kajian teori, dan metodologi penelitian. Dengan melihat hasil penelitian sejenis diharapkan bisa memberi masukan dan model untuk menyusun disertasi sendiri.

Topik menulis sengaja dipilih oleh penulis karena pertimbangan praktis dan akademis. Secara praktis, penulis sebelumnya mendalami menulis dan membuat penelitian tesis magister tentang menulis esai. Ini memberi kontribusi yang substansial bagi penulis karena penulis memiliki akses kuat untuk mendapatkan bahan pustaka, pengembangan topik, analisis, metode penelitian, dan hal-hal lain yang memudahkan penelitian. Secara akademis, penulis sudah memiliki pengalaman empiris di bidang penelitian menulis sehingga akan terbantu dari segi pengetahuan, pengalaman, dan kompetensi. Pengalaman empiris dan ketertarikan terhadap bidang kajian merupakan 
CENDEKIA, Vol. 12, No. 2, Oktober 2018

p-ISSN: 1978-2098; e-ISSN: 2407-8557

Http://cendekia.pusatbahasa.or.id; Email: cendekiaoslo@gmail.com

Center of Language and Cultural Studies, Surakarta, Indonesia

Budiharso, Teguh. 2018. Pembelajaran Menulis Esai dalam Disertasi: Kajian Metakognitif.

Cendekia (2018), 12(2): 141-152. DOI:10.30957/cendekia.v12i2.535.

salah satu motivator penting seorang peneliti untuk melaksanakan penelitian. Tanpa didorong rasa tertarik dan tidak memiliki motivasi cukup karena bidang yang dikaji belum dikuasai bisa menyebabkan penelitian dikerjakan lebih lama, lambat dan kurang bergairah.

Menulis disertasi mengharuskan mahasiswa melakukan kajian pustaka secara akurat dan mendalam. Akurat karena disertasi harus menunjukkan keaslian tulisan (roginality) dan kebaruan. Aspek kemendalaman disertasi dipenuhi melalui ketersediaan kajian pustaka, rujukan dan sumber-sumber yang diperoleh dari berbagai rujukan terutama jurnal internasional.

Menurut Connor (1996) kemampuan menulis tidak bisa diajarkan, tetapi harus dilatih. Yang bisa diajarkan ialah aspek tertentu dalam menulis, yaitu content, organization, language use dan mechanics. Untuk memperoleh ide, istilah dan gaya bahasa, pembelajar bisa mengukuti model tertentu dan menirunya untuk membuat tulisan sendiri. Ide, kosa kata, diksi, dan gaya bahasa bisa diperoleh melalui membaca karya sejenis atau hasil penelitian lain. Menulis bukanlah semata-mata muncul sebagai talenta tetapi hasil kerja keras yang harus dilatih secara sabar, telaten dan intensif, mulai dari persiapan, penulisan draft, revisi dan publikasi (Krashen, 1984:33; Connor, 1996:100, Budiharso, 2007:1 \& Solikhah, 2016).

Sadtono (1995) meneliti 22 mahasiswa program doktor UM tetantang kemampuan membaca dan menulis. Mahasiswa diberi test TOEFL, dan diwajibkan membaca sejumlah referensi. Setelah itu, mahasiswa diminta menulis makalah dengan rentangan 3.000-7.000 kata. Hasil analisis menunjukkan bahwa hanya 40\% mahasiswa yang mengungkapkan dengan baik kosa kata, ide, gaya tulisan, dan penggunaan retorika mengikuti gaya dalam referensi yang dibaca. Kajian lebih mendalam menunjukkan bahwa 40\% mahasiswa tersebut menggunakan teknik membaca evaluatif dengan cermat.

Menurut Solikhah (2016) deskripsi ini bisa dikaitkan juga dengan jumlah kosa kata dan gramatika yang digunakan. Dalam konteks bahasa Inggris, tingkat kemampuan membaca teks dengan kosa kata sekurang-kurangnya level advanced menjadi persoalan tersendiri. Kosa kata umum 1.000-3.000 (intermediate), 4.000 (preadvanced) ialah kosa kata minimum yang wajib dikuasasi mahasiswa. Adapun kosa kata standar ialah kosa kata 5.000 (advanced). Untuk teks akademik, mahasiswa juga memerlukan Academic Vocabulary List, daftar 400-750 kosa kata yang sering digunakan dalam buku teks, presentasi, dan aktifitas akademis lainnya, sebagai standar penguasaan literasi. Penggunaan teks berbahasa Indonesia atau bahasa Inggris, bukanlah hal yang perlu dipersoalkan di sini karena bahasa Inggris digunakan untuk buku, referensi, jurnal, dan dokumen atau sumber belajar lainnya secara global.

Selain kalimat akademik karya ilmiah juga perlu diperhatikan dengan cermat agar membaca kritis dan evaluatif bisa lebih tajam. Sumber-sumber ilmiah berupa jurnal, ensiklopedia, buku dan dokumen resmi yang ditulis dalam bahasa Inggris cendekung disusun dalam bentuk kalimat majemuk atau kalimat kompleks yang mengandung beberapa klausa. Kalimat seperti ini memerlukan kajian yang cermat jika pembaca akan menangkap isinya secara baik dan benar. Jika pembaca belum terbiasa menganalisis kalimat seperti ini makna yang akan ditangkap bisa berbeda dan akhirnya 
CENDEKIA, Vol. 12, No. 2, Oktober 2018

p-ISSN: 1978-2098; e-ISSN: 2407-8557

Http://cendekia.pusatbahasa.or.id; Email: cendekiaoslo@gmail.com

Center of Language and Cultural Studies, Surakarta, Indonesia

Budiharso, Teguh. 2018. Pembelajaran Menulis Esai dalam Disertasi: Kajian Metakognitif.

Cendekia (2018), 12(2): 141-152. DOI:10.30957/cendekia.v12i2.535.

tidak bisa melakukan membaca kritis atau evaluatif. Penggunaan gaya kalimat seperti ini tidak jauh berbeda dengan gaya yang digunakan dalam teks-teks berbahasa Indonesia baik yang asli ditulis penurut Indonesia atau teks terjemahan dari bahasa asing ke dalam bahasa Indonesia (Solikhah, 2016).

\section{METODE}

Kajian diarahkan pada penggalian metodologi penelitian dan topik penelitian di bidang menulis. Metodologi penelitian mengarahkan dan membentuk kerangka pikir bagaimana suatu design penelitian dilaksanakan, disertai dengan kajian landasan teori, pengajian hasil, dan temuan penelitian. Ary (1985) mengemukakan kajian terhadap penelitian sejenis memiliki keuntungan antara lain: membantu peneliti membuat rumusan masalah, membantu peneliti menemukan kerangka teori dan sumber rujukan, membantu peneliti mengidentifikasi metodologi penelitian yang meliputi: design, teknik sampling, instrumen dan teknik pengembangannya, teknik analisis data, dan hasil penelitian. Informasi empiris mengenai kajian penelitian sejenis tersebut membantu peneliti untuk menentukan metode yang akan dipilih, kajian teori yang diperlukan, dan prediksi hasil penelitian yang diharapkan.

Topik menulis dijadikan fokus kajian dimaksudkan untuk menggali lebih jauh design penelitian, trend terbaru di bidang menulis, dan pengembangan jenis penelitian yang memungkinkan untuk lebih diperdalam. Fokus tersebut merupakan sumbangan yang penting untuk merancang penelitian disertasi yang akan dilakukan penulis.

Sumber data kajian ini ialah empat disertasi bidang pendidikan bahasa Inggris. Keempat disertasi tersebut semuanya membahas topik menulis esai. Disertasi tersebut ialah (1) M. Adnan Latief (1990) berjudul Assessment of English Writing Skills for Students of English as a Second Language at IKIP Malang Indonesia; disertasi di Iowa University, (2) Nur Mukminatien (1997) berjudul The Differences of Students' Writing Achievement Across Different Course Levels, disertasi di IKIP Malang, (3) I. Harjanto (1999) berjudul English Academic Writing Features by Indonesian Learners of English, disertasi untuk IKIP Malang, dan (4) Teguh Budiharso (2001) berjudul Rhetoric and Linguistic Features of English and Indonesian Essays by EFL Undergraduate Students, disertasi untuk UM.

Analisis yang digunakan dalam kajian ini melibatkan tiga hal: analisis isi, kajian dokumen, dan metakognitif. Disebut content analysis karena kajian ditekankan pada penggalian isi teks untuk dilihat makna yang terkandung di dalamnya. Disebut kajian dokumen karena sumber teksnya berupa dokumen yaitu disertasi. Sedangkan kajian ini disebut juga metakognitif karena fokus kajian berupa hasil penelitian. Berdasarkan hasil penelitian yang dikaji tersebut, penulis mencoba menemukan bentuk tertentu sebagai hasil sintesis sumber-sumber yang diteliti yang bisa dilakukan dalam jenis penelitian yang lain.

\section{HASIL}

\subsection{Writing Assessment}

Disertasi ini judul lengkapnya ialah ialah Assessment of English Writing Skills for Students of English as a Second Language at IKIP Malang Indonesia; ditulis oleh 
CENDEKIA, Vol. 12, No. 2, Oktober 2018

p-ISSN: 1978-2098; e-ISSN: 2407-8557

Http://cendekia.pusatbahasa.or.id; Email: cendekiaoslo@gmail.com

Center of Language and Cultural Studies, Surakarta, Indonesia

Budiharso, Teguh. 2018. Pembelajaran Menulis Esai dalam Disertasi: Kajian Metakognitif. Cendekia (2018), 12(2): 141-152. DOI:10.30957/cendekia.v12i2.535.

M. Adnan Latief (1994) untuk program Ph.D. di Iowa University. Topik yang dikaji ialah pengembangan instrumen untuk menguji menulis esai dan teknik penilaiannya. Permasalahan disertasi difokuskan pada akurasi penggunaan penilaian menulis esai menggunakan analytic scoring system, primary traits scoring system, dan menggunakan holistic scoring system.

Dua landasan teori utama yang digunakan ialah teori tentang penilaian dan teori tentang menulis esai. Teori penilaian menguraikan bagaimana evaluasi hasil belajar diterapkan secara benar sesuai dengan tujuan pembelajaran dan karakteristik bahan ajar. Dalam teori ini, dikembangkan model pengembangan tes untuk menulis dan teknik penilaian yang dianggap paling sesuai dengan karakteristik esai. Teori ini menyimpulkan bahwa teknik penilaian yang relevan dengan pembelajaran menulis ialah penilaian unsur-unsur dalam tulisan (traits scoring system) dan penilaian menyeluruh isi tulisan (holistic scoring system). Pada model traits scoring system, penilaian diarahkan pada akurasi unsur-unsur bahasa dalam tulisan, seperti jenis kalimat (syntax), struktur kalimat, penggunaan kosa kata, dan mekanik tulisan. Pada holistic scoring system, penilaian ditekankan pada organisasi, substansi, sintaksis, gramatika dan mekanik.

Penelitian ini menggunakan design pengembangan dengan pendekatan kuantitatif dan kualitatif. Pendekatan kuantitatif digunakan untuk menganilsis akurasi sistem skoring sedangkan pendekatan kualitatif digunakan untuk menemukan jenis produk berupa soal menulis dan kriteria teknik penilaian menulis esai. Jumlah sampel yang diteliti sebanyak 120 orang terdiri dari mahasiswa semester III, V, dan VII. Tiga kelompok mahasiswa sengaja dipilih karena penelitian juga bertujuan untuk melacak bagaimana perbedaan penguasaan gramatika dan penguasaan variasi kalimat bagi mahasiswa yang sedang dan sudah belajar matakuliah gramatika. Instrumen yang digunakan berupa writing prompt (perintah dalam soal menulis) dan model penilaian menulis. Analisis dilakukan secara kuantitatif dan kualitatif.

Penelitian ini menunjukkan hasil sebagai berikut. Primary traits scoring system lebih cocok digunakan untuk menilai esai yang dibuat oleh mahasiswa yang levelnya lebih rendah. Hal ini disebabkan mahasiswa tingkat lebih rendah belum menguasai gramatika dengan baik, kosa kata masih terbatas, dan frekuensi menulis ilmiah masih kurang.

Teknik penilaian analytic memiliki kesamaan dengan primary traits scoring system karena deskripsi penilaian diarahkan pada bagian-bagian penting suatu tulisan yang mengkaji bagian yang lebih rinci. Analytic scoring system menekankan pada kesalahan bahasa dalam tulisan yang meliputi variasi kalimat, gramatika, diksi, dan kesalahan mekanik.

Sebaliknya holystics scoring system lebih cocok untuk mahasiswa yang berada pada tingkatan lebih tinggi sudah memperoleh matakuliah gramatika, menulis, membaca dan juga sudah mengerjakan berbagai tugas yang hakikatnya karya ilmiah yang bisa dianggap sebagai latihan menulis. Penelitian ini juga menemukan bahwa mahasiswa yang sudah tinggi tingkatan semesternya tidak secara otomatis mampu menulis kalimat dengan variasi klausa yang lebih tinggi. Begitu juga menggunaan kosa kata yang bervariasi, tidak muncul begitu saja pada mahasiswa yang berada di semester lebih tinggi. Temuan lain ialah kesalahan mekanik muncul di semua tingkatan baik 
CENDEKIA, Vol. 12, No. 2, Oktober 2018

p-ISSN: 1978-2098; e-ISSN: 2407-8557

Http://cendekia.pusatbahasa.or.id; Email: cendekiaoslo@gmail.com

Center of Language and Cultural Studies, Surakarta, Indonesia

Budiharso, Teguh. 2018. Pembelajaran Menulis Esai dalam Disertasi: Kajian Metakognitif.

Cendekia (2018), 12(2): 141-152. DOI:10.30957/cendekia.v12i2.535.

mahasiswa pada semester rendah maupun pada semester tinggi. Penelitian ini merekomendasikan bahwa traits scoring system dan holystic scoring system bisa digunakan kedua-duanya. Selain itu, menulis merupakan proses jadi penguasaan gramatika tidak menjamin mahasiswa bisa menulis dengan baik.

\subsection{Writing Across Course Levels}

Penelitian ini dikerjakan oleh Nur Mukminatien (1997) untuk disertasi doktor di IKIP Malang. Judul lengkap penelitian ialah The Differences of Students' Writing Achievement Across Different Course Levels. Permasalahan penelitian ini ialah untuk melihat apakah terdapat perbedaan yang signifikans antara mahasiswa yang diajar gramatika secara intensif dibandingkan dengan yang diberi perlakukan koreksi kalimat pada pekerjaan esainya; dan untuk melihat perbedaan kualitas kalimat dalam esai mahasiswa yang belajar gramatika pada semester yang lebih rendah dengan mahasiswa pada semester yang lebih tinggi.

Landasan teori yang digunakan sebagai kerangka pikir ialah pembelajaran menulis terbimbing dengan cara diberi eksposur berbeda. Pertama, menulis diasumsikan dipengaruhi oleh penguasaan gramatika. Hal ini merupakan landasan untuk memberi treatments koreksi gramatika dan frekuensi menulis. Kedua, dari segi teori pemerolehan bahasa kedua, penelitian ini bermaksud menguji pengaruh bahasantara terhadap kualitas tulisan. Diasumsikan semakin tinggi penguasaan aturanaturan bahasa Inggris, akan semakin baik kualitas kalimat dalam esai.

Penelitian ini menggunakan design eksperimen cross sectional, pengamatan dilakukan secara terus menerus dalam kurun waktu tertentu beberapa kali. Sampel yang digunakan sebagai subjek penelitian ialah mahasiswa semester II, semester IV dan semester VI. Setiap grup mahasiswa diberi treatment pembelajaran gramatika dan koreksi kalimat dalam esai. Instrumen yang digunakan ialah tes menulis yang dikoreksi menggunakan traits scoring system dan holistic scoring system. Teknik analisis yang digunakan ialah SPSS.

Penelitian menghasilkan hal-hal berikut. Pertama, tidak terdapat perbedaan yang signifikans antara penguasaan gramatika dan koreksi kalimat dalam peningkatan kualitas esai yang dibuat mahasiswa pada semua tingkatan. Kedua, penguasaan gramatika tidak menyebabkan peningkatan kualitas kalimat dalam esai semakin bervariasi. Ketiga, penggunaan traits scoring system dan holistic scoring system tidak menunjukkan berbedaan kualitas esai. Penelitian ini menindaklanjuti penelitian Latief (1994) dan merekomendasikan bahwa pembelajaran gramatika dalam upaya meningkatkan kualitas tulisan perlu dipertimbangkan. Pembelajaran menulis dianjurkan menggabungkan baik latihan menulis intensif, koreksi gramatika dalam kalimat, dan frekuensi menulis. Penguasaan gramatika yang tinggi tidak menyebabkan kemampuan menulis kalimat dalam bahasa Inggris menjadi bervariasi karena pembelajar menerapkan aturan gramatika dalam Bahasa Indonesia.

\subsection{English Academic Writing Features}

Penelitian Ignatius Harjanto (1999) ini judul lengkapnya English Academic Writing Features by Indonesian Learners of English. Permasalahan yang dikaji ialah 
CENDEKIA, Vol. 12, No. 2, Oktober 2018

p-ISSN: 1978-2098; e-ISSN: 2407-8557

Http://cendekia.pusatbahasa.or.id; Email: cendekiaoslo@gmail.com

Center of Language and Cultural Studies, Surakarta, Indonesia

Budiharso, Teguh. 2018. Pembelajaran Menulis Esai dalam Disertasi: Kajian Metakognitif.

Cendekia (2018), 12(2): 141-152. DOI:10.30957/cendekia.v12i2.535.

bagaimana pola retorika yang digunakan mahasiswa program S2 Pendidikan Bahasa Inggris IKIP Malang dalam karya ilmiah. Pola retorika dikelompokkan ke dalam retorika linier, sirkuler, dan non-linear. Retorika dilihat dari keberadaan thesis, kesesuaian judul dengan thesis, kesesuaian thesis dengan paragraf pengembang, dan thesis dengan paragraf penutup.

Penelitian ini berusaha menguji teori menulis dipengaruhi oleh faktor budaya. Teori Shapir-Whorf dan analisis wacana digunakan landasan teori utama dan pola retorika yang dikembangkan Kaplan (1980) digunakan sebagai kriteria pembahasan. Dari aspek isi tulisan dan pola-pola pengembangan ide, penelitian ini berusaha mengidentifikasi model retorika seperti teori Kaplan (1980). Sedangkan dari segi wacana penelitian ini mengkaji bagaimana teks esai bahasa Inggris yang ditulis oleh mahasiswa jurusan bahasa Inggris memiliki kemiripan dengan kriteria tulisan penutur asli.

Design penelitian ialah analisis isi dengan kajian analisis wacana sebagai alat analisis. Sumber data yang digunakan ialah 10 paper mahasiswa S2 yang dikumpulkan sebagai tugas akhir semester. Selain itu, Harjanto menggunakan angket dan wawancara untuk menjaring data. Sebagai analisis isi dengan pendekatan kualitatif, penelitian ini menggali pola-pola retorika pada tataran paragraf dan esai. Analisis dilakukan menggunakan model pengembangan esai yang meliputi kesesuaian paragraf pengantar, paragraf isi, dan paragraf penutup.

Penelitian ini menghasilkan temuan berikut. Pertama, karya ilmiah berbahasa Inggris yang dibuat mahasiswa S2 untuk tugas akhir semester tidak sama dengan pola yang dibuat oleh penutur asli bahasa Inggris. Pola penyusunannya sama tetapi isinya tidak sama dengan tulisan penutur asli. Kedua, pola penggunaan retorika dalam karya ilmiah yang dikaji tidak sama: karya ilmiah ini menggunakan pola sirkuler sedangkan penutur asli bahasa Inggris menggunakan pola linier. Ketiga, strategi pengembangan retorika tidak selalu memperhatikan dukungan fakta, rujukan atau pendapat penulis. Penelitian ini menyimpulkan bahwa perubahan pola retorika mahasiswa bahasa Inggris dalam menulis karya ilmiah berbahasa Inggris baru dalam tahap perubahan: dari pola sirkuler ke linear. Pola yang digunakan bisa linear tetapi sekaligus juga non-linear. Salah satu penyebabnya ialah mahasiswa menggunakan pola wacana lisan untuk menuangkan ide dalam bentuk tulisan.

\subsection{Contrastive Rhetoric}

Disertasi terakhir yang dikaji ialah tulisan Teguh Budiharso (2001) berjudul Rhetoric and Linguistic Features of English and Indonesian Essays by EFL Undergraduate Students. Permasalahan dalam penelitian ini ialah perbandingan pola retorika yang ditulis oleh mahasiswa yang sedang menulis skripsi dalam bentuk esai argumentatif berbahasa Inggris dan berbahasa Indonesia. Selain itu, penelitian juga mengkaji perbedaan aspek lingustik dalam esai bahasa Inggris dan bahasa Indonesia yang meliputi: variasi kalimat (sintaksis), gramatika, kosa kata dan mekanik (penggunaan tanda baca, huruf kapital, simbol matematis dan teknik pengetikan).

Penelitian ini berusaha mengkaji teori contrastive rhetoric dalam pembelajaran menulis. Selain menggabungkan teori Kaplan tentang retorika, kajian teori juga 
CENDEKIA, Vol. 12, No. 2, Oktober 2018

p-ISSN: 1978-2098; e-ISSN: 2407-8557

Http://cendekia.pusatbahasa.or.id; Email: cendekiaoslo@gmail.com

Center of Language and Cultural Studies, Surakarta, Indonesia

Budiharso, Teguh. 2018. Pembelajaran Menulis Esai dalam Disertasi: Kajian Metakognitif.

Cendekia (2018), 12(2): 141-152. DOI:10.30957/cendekia.v12i2.535.

mengulas bagaimana model penulisan karya ilmiah yang dianggap standar yaitu berpola linear. Secara spesifik, unsur-unsur dalam tulisan dikaji melalui teori menulis paragraf, menulis esai, dan pendekatan proses dalam belajar menulis yang meliputi: pramenulis, menyusun draft, merevisi, dan mengedit.

Design penelitian ialah content analysis dengan pendekatan kualitatif. Subjek yang diteliti ialah 10 mahasiswa program S1 di Universitas Muhammadiyah Malang yang sedang menyusun skripsi. Instrumen yang digunakan terdiri dari empat jenis: tes menulis esai berbahasa Inggris, tes menulis esai berbahasa Indonesia, angket, dan wawancara. Analisis dimaksudkan untuk mengidentifikasi perbedaan pola retorika linier dan non-liniear dalam esai berbahasa Inggris dan berbahasa Indonesia dengan cara membandingkan. Selain itu, strategi menulis juga dilihat untuk memastikan perbedaan pola retorika yang digunakan mahasiswa.

Hasil penelitian dikelompokkan ke dalam dua jenis: pola retorika dan penggunaan aspek kebahasaan. Terdapat dua jenis pola retorika dalam esai yang ditulis dalam bahasa Inggris dan yang ditulis dalam bahasa Indonesia. Mahasiswa yang memiliki kebiasaan menulis bahasa Indonesia dengan baik memiliki pola retorika yang sama dalam menulis bahasa Inggris, yaitu pola retorika linear yang ditandai dengan adanya judul sesuai tema, paragraf pengantar berisi tesis, paragraf pengembang untuk menguraikan tesis, dan paragraf penutup untuk meringkas isi tesis dan uraian dalam paragraf penutup. Sebaliknya, mahasiswa yang belum terbiasa menulis atau frekuensi menulis esai baik menggunakan bahasa Indonesia atau bahasa Inggris kurang, cenderung menggunakan pola retorika non-linear. Struktur esai terdiri dari pembuka, isi, dan penutup tetapi isi pada masing-masing paragraf tidak sesuai dengan kriteria paragraf yang baik. Alasan yang disampaikan mahasiswa ialah karena mereka menggunakan strategi yang sama dalam menulis esai berbahasa Inggris atau bahasa Indonesia. Dalam menulis bahasa Inggris umumnya mahasiswa terlebih dulu membuat draft menggunakan bahasa Indonesia kemudian diterjemahkan ke dalam bahasa Inggris.

Strategi demikian nampak dalam segi linguistik. Dari segi linguistik, baik mahasiswa yang berpengalaman atau yang kurang berpengalaman menulis, tidak menggunakan variasi kalimat majemuk atau kalimat kompleks yang terdiri dari beberapa klausa. Kalimat fragmen yang tidak memiliki subjek atau tidak memiliki predikat muncul di sana sini. Dalam esai berbahasa Inggris kesalahan gramatika tingkat dasar seperti tenses, gramatika, agreements, plurality muncul cukup produktif. Dalam esai berbahasa Indonesia kekeliruan gramatika dan penggunaan kosa kata muncul dalam bentuk jargon dan pola kalimat bahasa Jawa karena pembelajar semuanya beretnis Jawa. Dalam esai berbahasa Inggris, kalimat dan kosa kata yang muncul ialah struktur bahasa Indonesia dengan nuance bahasa Indonesia. Ini disebabkan terutama mahasiswa membuat draft dalam bahasa Inggris kemudian diterjemahkan ke dalam bahasa Indonesia. Dari segi mekanik, baik esai berbahasa Inggris maupun berbahasa Indonesia memiliki kekeliruan yang hampir sama: penggunaan tanda baca, huruf kapital, simbol matematis seperti dalam kurung, persentase. Misalnya tanda Tanya, tanda dalam kurung, simbol (\%) persentase diberi spasi dengan huruf. Ini menunjukkan bahwa mahasiswa belum terlatih menulis dengan baik dan benar dan tulisan yang sudah selesai dalam bentuk draft cenderung tidak direvisi atau tidak diedit. Penelitian ini 
CENDEKIA, Vol. 12, No. 2, Oktober 2018

p-ISSN: 1978-2098; e-ISSN: 2407-8557

Http://cendekia.pusatbahasa.or.id; Email: cendekiaoslo@gmail.com

Center of Language and Cultural Studies, Surakarta, Indonesia

Budiharso, Teguh. 2018. Pembelajaran Menulis Esai dalam Disertasi: Kajian Metakognitif.

Cendekia (2018), 12(2): 141-152. DOI:10.30957/cendekia.v12i2.535.

merekomendasikan penggunaan contrastive rhetoric dan pendekatan proses dalam mengajar menulis baik untuk pembelajaran di kelas maupun proses bimbingan skripsi.

\section{BAHASAN}

\subsection{Manfaat Umum Kajian}

Empat disertasi tersebut menggunakan dua pendekatan utama: dua kuantitatif dan dua lainnya kualitatif. Pendekatan kuantitatif yang digunakan Latief (1994) dan Mukminatien (1997) menekankan untuk menguji teori dan mengembangkan instrumen yang ditetapkan berdasarkan kriteria baku yang dikemukakan dalam teori-teori yang dirujuk. Penggunaan uji statistik merupakan teknik utama dalam design ini dan jumlah variabel yang kompleks, ditandai dengan pelibatan berbagai unsur merupakan kekuatan penelitian.

Dalam disertasi yang menggunakan pendekatan kualitatif dalam Harjanto (1999) dan Budiharso (2001) penelitian juga menguji teori, tetapi kajian lebih variatif dan lebih longgar. Peneliti tidak semata-mata mengkonfirmasi teori yang dirujuk tetapi juga mencoba membuat modifikasi terhadap konsep yang sudah ada. Kedua pola dalam penelitian kuantitatif dan kualitatif tersebut sejalan dengan karakteristiknya; penelitian kuantitatif dirancang dengan ketat sebelum penelitian dan rumusan masalah ditetapkan sebelumnya setelah mengkaji landasan teori yang mantap (Fraenkel dan Wallen, 1990; Ary, 1985), sedangkan penelitian kualitatif, kerangka teori dan permasalahan bersifat sementara sebagai grounded theory yang harus diubah atau dimodifikasi sesuai dengan kondisi lapangan setelah penelitian dilakukan (Bogdan and Biklen, 1992; Fraenkel dan Wallen, 1990).

Aspek kedua yang juga mendasar dari hasil kajian empat disertasi tersebut ialah kesinambungan kajian teori dan upaya pengembangan penelitian sebelumnya. Latief (1994) mengembangkan model penilaian menulis, pola tes yang sesuai dengan jenis esai dan pengaruh pembelajaran gramatika terhadap kualitas esai. Temuan ini ditindaklanjuti oleh Mukminatien (1997) dalam design eksperimen dengan menambahkan treatment sebagai pembanding. Temuan utama penelitian Mukminatien (1997) ialah mengkofirmasi temuan Latief (1994) yang menegaskan bahwa penguasaan gramatika tidak mempengaruhi kualitas variasi kalimat dalam esai. Mukminatien (1997) juga menemukan bahwa mahasiswa jurusan bahasa Inggris cenderung menggunakan aturan gramatika bahasa Indonesia untuk menulis kalimat bahasa Inggris.

Harjanto (1999) walaupun tidak secara eksplisit mengembangkan temuan Latief (1994) dan Mukminatien (1997), menyebutkan bahwa penguasaan gramatika dalam esai dipengaruhi oleh faktor budaya. Karena itu, faktor budaya yang tertuang dalam pola kalimat, pola pengungkapan ide, dan pola penyusunan alasan dalam teks bisa dilacak dari pola retorika. Penelitian ini dengan demikian memadukan antara faktor bahasa dan faktor pola pikir, terutama pola pikir dan argumen dalam bahasa lisan untuk dibandingkan dengan esai bahasa Inggris. Walaupun pembelajar adalah mahasiswa program S2 Bahasa Inggris dan memiliki pengalaman mengajar bahasa Inggris rata-rata 10 tahun, tidak dengan sendirinya pola retorika bahasa Inggris dikuasai. Hal ini menarik perhatian Harjanto (1999) dan diteliti melalui teks tertulis berupa makalah tugas akhir perkuliahan. 
CENDEKIA, Vol. 12, No. 2, Oktober 2018

p-ISSN: 1978-2098; e-ISSN: 2407-8557

Http://cendekia.pusatbahasa.or.id; Email: cendekiaoslo@gmail.com

Center of Language and Cultural Studies, Surakarta, Indonesia

Budiharso, Teguh. 2018. Pembelajaran Menulis Esai dalam Disertasi: Kajian Metakognitif.

Cendekia (2018), 12(2): 141-152. DOI:10.30957/cendekia.v12i2.535.

Seiring dengan semakin berkembangnya analisis kontrastif dalam menulis, Budiharso (2004) menggabungkan temuan Latief (1994), Mukminatien (1997), dan Harjanto (1999). Analisis dikembangkan lebih luas dengan mengkaji secara khusus aspek bahasa yang dirujuk dari penelitian Wahab (1997) dan Krashen (1981). Temuan Budiharso (2001) memberi konfirmasi pola retorika temuan Harjanto (1999), dan pola penyusunan kalimat temuan Krashen (1981), Latief (1994) dan Mukminatien (1997). Hasil penelitian Budiharso ini dipublikasi dalam jurnal TEFLIN (2006a), Bahasa dan Sastra (2006b), dan dua buah buku Rhetoric and Lingistic Features (Penerbit Certelbook, 2006c), dan Contrastie Rheoric (penerbit Cawanmas, 2008).

Analisis ini memberi petunjuk bahwa penelitian berkembang sesuai dengan trend keilmuan dan isu bidang kajian. Perkembangan kajian menulis dari aspek bahasa, berkembang ke dalam aspek retorika, analisis wacana, dan analisis kontrastif. Bidang kajian tersebut dikembangkan sesuai dengan jenis design penelitian yang menguji berbagai aspek untuk memberi konfirmasi atau memodifikasi temuan sebelumnya; bermula dari kajian kuantitatif menuju kualitatif dengan fokus yang bervariasi. Pola pengembangan demikian ini memberi input dan inspirasi baru bagi calon peneliti untuk menemukan design baru, memodifikasi design yang ada, atau menggabungkan beberapa design atau isu untuk dibuat dalam design yang dikehendaki.

\subsection{Hasil Kajian untuk Rujukan Penelitian Baru}

Sesuai dengan hasil kajian dan uraian dalam pembahasan, penulis berkesimpulan bahwa penelitian baru bisa dikembangkan dengan cara membaca penelitian sebelumnya. Analisis yang memfokuskan pada hasil-hasil penelitian yang sudah dilakukan sebelumnya untuk menemukan hasil tersendiri ini disebut dengan kajian metakognitif. Dalam kajian ini, penulis menyimpulkan ada tiga pola yang bisa dikembangkan untuk menyusun design penelitian baru: replikasi, modifikasi, atau mengembangkan pola berdasarkan model dari beberapa penelitian sebelumnya. Aspek yang dikembangkan bisa diambil dari variabel atau metodologi penelitian yang digunakan sebelumnya.

Untuk kajian ini penulis merumuskan dua model penelitian yang bisa dikembangkan dalam rencana penelitian calon disertasi yang penulis geluti. Pertama, dalam pendekatan kualitatif, penelitian direncanakan mengkaji secara lebih mendalam kualitas esai dengan menggali informasi meluas terkait dengan frekeunsi membaca, frekuensi menulis, intensitas koreksi kalimat dan proses menulis. Kedua, dalam pendekatan kuantitatif, topik penelitian tersebut bisa dimodifikasi menjadi pengaruh frekuensi membaca, frekuensi menulis, proses menulis, dan intensitas koreksi kalimat terhadap kualitas esai.

Dalam pendekatan kualitatif, penelitian bisa dilaksanakan dengan fokus kajian mendalam terhadap satu grup subjek. Design ini cocok untuk subjek yang sudah terbiasa menulis karya ilmiah secara mendalam, misalnya skripsi atau tesis program master. Kajian diarahkan untuk melihat kualitas esai, tesis yang sudah jadi, atau artikel yang dimuat di jurnal. Untuk memperdalam kajian, peneliti memberikan angket dan wawancara yang diarahkan untuk menggali informasi dari segi peranan frekuensi membaca sumber untuk meningkatkan kualitas tulisan, frekuensi dan pengalaman menulis karya ilmiah, proses menulis yang meliputi: pramenulis, penyusunan draft, 
CENDEKIA, Vol. 12, No. 2, Oktober 2018

p-ISSN: 1978-2098; e-ISSN: 2407-8557

Http://cendekia.pusatbahasa.or.id; Email: cendekiaoslo@gmail.com

Center of Language and Cultural Studies, Surakarta, Indonesia

Budiharso, Teguh. 2018. Pembelajaran Menulis Esai dalam Disertasi: Kajian Metakognitif.

Cendekia (2018), 12(2): 141-152. DOI:10.30957/cendekia.v12i2.535.

revisi, dan editing; serta peranan koreksi kalimat. Dengan design kuantitatif, instrumen yang lebih utama ialah peneliti sebagai instrumen kunci yang bekerja untuk mengkaji secara mendalam sumber data tertulis dan membuat kajian-kajian aspek kualitas tulisan dengan merujuk pada kriteria karya ilmiah yang baik.

Dalam pendekatan kuantitatif, penelitian dilakukan dalam bentuk eksperimen. Variabel independent yang akan dibandingkan sebanyak empat yaitu: frekuensi membaca, frekuensi menulis, proses menulis, dan koreksi kalimat. Variabel dependent tang dikaji ialah kualitas karya ilmiah dalam bentuk esai. Penelitian ini memerlukan kajian lapangan yang diberikan dalam bentuk treatment. Untuk itu, diperlukan empat kelompok tercoba yang masing-masing akan diberi treatment berbeda. Kelompok pertama diberi treatment membaca teks dalam frekuensi tertentu untuk mendorong kemampuan menulis esai. Kelompok kedua, ketiga dan keempat masing-masing diberi treatment berupa latihan latihan menulis esai terus-menerus, koreksi kalimat dan struktur gramatika, dan proses menulis yang dilatihkan melalui pramenulis, menyusun draft, merevisi, dan mengedit.

Sebagai penelitian kuantitatif, instrumen dikembangkan lebih dulu dengan melalui ujicoba untuk memperoleh kualitas butir yang baik. Instrumen yang digunakan ialah: angket untuk menjaring informasi mengenai frekuensi membaca, frekuensi menulis, koreksi kalimat, dan proses menulis. Instrumen lain yang diperlukan ialah writing promt untuk esai. Karena karakteristik penelitian yang demikian ini, subjek penelitian yang lebih cocok ialah mahasiswa program S1 yang sudah memiliki cukup skemata menulis, misalnya semester VI atau semeser VII.

\section{SIMPULAN}

Kajian disertasi untuk menimbulkan ide rencana penelitian disertasi ini dilakukan terhadap empat disertasi bahasa Inggris yang tersedia di UM. Keempat disertasi yang dikaji ialah tulisan Latief (1994), Mukminatien (1997), Harjanto (1999), dan Budiharso (2001). Disertasi dikelompokkan ke dalam dua design: dua yang pertama ialah design kuantitatif dan dua yang terakhir ialah kualitatif. Keempat disertasi tersebut semuanya membahas kualitas esai dilihat dari aspek kesesuaian teknik scoring, kemampuan menyusun kalimat, ratorika, dan perbandingan retorika dalam esai berbahasa Inggris dan berbahasa Indonesia.

Hasil kajian menunjukkan bahwa keempat penelitian tersebut bersifat pengembangan dan diilhami oleh temuan dari penelitian sebelumnya. Pengembangan bisa dilakukan dengan cara replikasi, modifikasi, atau pengembangan design baru. Aspek yang dikembangkan bisa dilakukan melalui variabel atau metodologi penelitian.

Kajian metagoknitif ini memberikan inspirasi pada penulis untuk membuat rencana penelitian di bidang menulis karya ilmiah atau esai. Dengan menggabungkan temuan-temuan penelitian yang dikaji, penulis sampai pada kesimpulan bahwa penelitian menulis masih bisa dilakukan dengan melibatkan lima variabel: kualitas esai, frekuensi membaca, frekuensi menulis, koreksi kalimat, dan proses menulis. Kelima variabel tersebut bisa dikembangkan dengan design kualitatif atau kualitatif. Sedangkan subjek yang diteliti bisa diarahkan untuk mahasiswa program S2 atau program S1 
CENDEKIA, Vol. 12, No. 2, Oktober 2018

p-ISSN: 1978-2098; e-ISSN: 2407-8557

Http://cendekia.pusatbahasa.or.id; Email: cendekiaoslo@gmail.com

Center of Language and Cultural Studies, Surakarta, Indonesia

Budiharso, Teguh. 2018. Pembelajaran Menulis Esai dalam Disertasi: Kajian Metakognitif. Cendekia (2018), 12(2): 141-152. DOI:10.30957/cendekia.v12i2.535.

jurusan bahasa. Dengan format kajian yang demikian, penulis memiliki frame berpikir untuk mengembangkan instrumen penelitian dalam bentuk angket dan writing prompt.

\section{DAFTAR PUSTAKA}

Ary, D. Jacobs, L.C. and Razavieh, A. 1985. Introduction to Research in Education.

New York: Rinehart and Winston Inc.

Berg, B.L. 1989. Qualitative Research Methods for the Social Sciences. London: Allyn and Bacon, Co.

Bogdan, R and Sari K.B. 1992. Qualitative Research for Education. Needham Heights: A Division of Simon \& Schuster Inc.

Brown, G. and Yule, G. 1981. Discourse Analysis. Cambridge: Cambridge University Press.

Budiharso, T. 2008. Contrastive Analysis on Rhetoric and Linguistic Features of Academic Essays. Yogyakarta: Penerbit Cawanmas.

Budiharso, T. 2006a. The Rhetoric Features of English and Indonesian Essays Made by EFL Undergraduate Students. TEFLIN Journal, 17(2):54-86.

Budiharso, T. 2006b. The Linguistic Features of English and Indonesian Essays Made by EFL Undergraduate Students. Bahasa dan Seni, Jurnal Bahasa, sastra, dan Pengajarannya, 34(1):1-18.

Budiharso, T. 2006c. Rhetoric and Linguistic Features: A Contrastive Rhetoric Analysis of Essay Writing. Yogyakarta: Steppapublishing.

Budiharso, T. 2001. Rhetoric and the Linguistic Features of English and Indonesian Essays by EFL Undergraduate Students. Unpublished Doctoraal Dissertation. Malang: State University of Malang.

Carson, J.E, Carrell, P.L. Silberstein, S., Kroll, B, and Kuehn, P.A. 1990. ReadingWriting Relationships in First and Second Language. TESOL QUARTERLY, 24(2):245-266.

Caudery, T. 1995. The Process Approach: Seminar Notes. Paper Presented in the British Council Summer School on Writing in the Classroom. Guildford: University of Surrey.

Connor, U. 1996. Contrastive Rhetoric: Cross-Cultural Aspects of Second Language Writing. Cambridge: Cambridge University Press.

Connor, U and J. Lauer. 1988. Cross-Cultural Variation in Persuasive Student Writing. In Writing Across Languages and Cultures. pp. 138-159. Newbury Park, CA: Sage Publication.

Fraenkel, J.R., and Wallen N.E. 1990. How to Design and Evaluate Research in Education. New York: McGraw-Hill Inc.

Harjanto, I. 1991. The Effect of Sentence Combining Practice on Students Writing Ability in Terms of Language Use. Unpublished Master's Thesis. Malang: IKIP MALANG.

Harjanto, I. 1999. English Academic Writing Features by Indonesian Learners of English. Unpublished Doctoral Dissertation. Malang: IKIP MALANG. 
CENDEKIA, Vol. 12, No. 2, Oktober 2018

p-ISSN: 1978-2098; e-ISSN: 2407-8557

Http://cendekia.pusatbahasa.or.id; Email: cendekiaoslo@gmail.com

Center of Language and Cultural Studies, Surakarta, Indonesia

Budiharso, Teguh. 2018. Pembelajaran Menulis Esai dalam Disertasi: Kajian Metakognitif. Cendekia (2018), 12(2): 141-152. DOI:10.30957/cendekia.v12i2.535.

Hartfiel, V.F., Hughey, J.B., Wormuth, D.R. Jacobs, H.L. 1985. Learning ESL Composition: English Composition Program. London: Newbury House Publishers, Inc.

Holsti, O.R. 1969. Content Analysis for Social Sciences and Humanities. Donn Mills, Ontario: Addison-Wesley Publishing.

Kaplan, R.B. 1980. Cultural Thought Patterns in Intercultural Education. In Croft (ed.) 1980. Readings on English as a Second Language for Teachers and Teacher Trainees. Boston: Little Brown and Co. pp. 399-418.

Krashen, S.D. 1981. Writing: Research, Theory, and Applications. Oxford: Pergamon Institute of English.

Krippendorff, K. 1980. Content Analysis: An Introduction to Its Methodology. London: Sage Publications.

Langan, J. 1986. College Writing Skills with Readings. London: McGraw-Hill Company.

Latief, M.A. 1990. Assessment of English Writing Skills for Students of English as a Second Language at IKIP MALANG Indonesia. Unpublished Ph.D. Dissertation. Iowa City, Iowa: The University of Iowa.

Miles M and M. Huberman. 1994. Qualitative Data Analysis: An Expanded Sourcesbook. Beverly Hills: SAGE Publication Inc.

Mukminatien, N. 1997. The Differences of Students' Writing Achievement Across Different Course Levels. Unpublished Doctoral Dissertation. Malang: IKIP MALANG.

Newman, I and Benz, C.R. 1998. Qualitative-Quantitative Research Methodology: Exploring the Interactive Continuum. Austin, Texas: Southern Illinois University Press.

Oshima, A. and Houge, A. 1991. Writing Academic English: A Writing and Sentence Structure Handbook. Second Edition. Cambridge: Addison-Wesley Publishing Company.

Solikhah, Imroatus. 2016. Refleksi dan Implikasi Penelitian Disertasi Doktor dan Menulis untuk Jurnal Internasional. Cendekia, 10(2):255-268.

Wahab, A. 1995. Indonesian Rhetoric in Intercultural Communication. The TEFLIN Silver Anniversary Seminar. Yogyakarta: IKIP Yogyakarta, Gajah Mada University, Sanata Dharma University, August, 2-5. 